\title{
Effects of In-Utero Exposure to Cadmium on the Brain Biogenic Amine Levels and Tissue Metal Distribution in Rats
}

\author{
R. C. MURTHY, M. MOHD. ALI and S. V. CHANDRA* \\ Metal Toxicity Project \\ Industrial Toxicology Research Centre \\ P. O. Box No. 80, Lucknow-226 001, India
}

(Received October 8, 1985 and in revised form November 20, 1985)

\begin{abstract}
The effects of cadmium in pups born to rats exposed, during the gestation period, to low levels of $\mathrm{Cd}\left(4.2\right.$ and $8.4 \mu \mathrm{g} \mathrm{Cd}^{2+} / \mathrm{ml}$ drinking water) on the brain biogenic amines and tissue metal distribution were studied. A significant increase in 5-HT level in whole brain was observed at day 1 of age, while after 90 days of withdrawal of treatment, increases in striatal DA and cortical 5-HT were evident. Zn level registered an increase in brain but a decrease in liver. Cu level was reduced in all the three regions studied, viz., brain, liver and kidney, at day 1 of age while after 90 days of withdrawal of treatment the effect persisted in liver. Cd levels showed significant increase only at day 1 of age. Our current findings reveal that exposure to even low levels of $\mathrm{Cd}$ during the early developmental stages might result in long lasting biochemical alterations in the young ones and some of the changes may persist even upto the adult stage.
\end{abstract}

Key words: In utero cadmium-Rat-Brain biogenic amines-Tissue metal distribution

\section{INTRODUCTION}

The neurotoxic effects of cadmium (Cd) have been well reported. ${ }^{1)}$ The risk of environmental contamination by $\mathrm{Cd}$ is of increasing concern due to its widespread industrial use. Human beings are exposed to $\mathrm{Cd}$ in food, water and air. The human body $\mathrm{Cd}$ content has been found to increase from less than $1 \mu \mathrm{g}$ in the new born to about $15-20 \mathrm{mg}$ in an adult in the UK and Sweden. ${ }^{2)}$

The importance of age with respect to the neurotoxicity of $\mathrm{Cd}$ has been well documented. ${ }^{3}$ Cd penetrates the fetal blood brain barrier with more ease in rats and causes hemorrhagic lesions in the brain. These facts and the prolonged biological half-life of $\mathrm{Cd}$ enhance its environmental hazard, especially in the young and immature organism. The present investigation was undertaken to study the effect of low level in utero exposure to $\mathrm{Cd}$, on the brain biogenic amine levels and tissue

* Correspondence to: Dr. (Mrs) S. V. Chandra MD, MRC Path (Lond), Industrial

Toxicology Research Centre, P. O. Box No. 80, Lucknow-226 001, India. 
metal distribution in rats.

\section{Materials AND MethodS}

30 uniparous, timed-pregnant rats of Wistar-derived strain, weighing 200-225 g were drawn from our laboratory animal facility. They were randomly divided into groups of 10 each and were housed individually in acrylic cages with animal bedding. The room temperature was maintained between $22-23^{\circ} \mathrm{C}$ with artificial lighting provided on a $12 \mathrm{hr}$ on/off cycle (on at $0600 \mathrm{hrs}$ ). The animals were provided with pellet diet (Hind Lever Laboratory Animal Feeds, India) and tap water ad libitum.

The experimental groups were exposed to either 4.2 or $8.4 \mu \mathrm{g} \mathrm{Cd}^{2+} / \mathrm{ml}$ (as cadmium acetate) drinking water throughout the gestation period. The diet and water consumption rates were measured on alternate days. All the animals were allowed to deliver normally.

\section{Brain Biogenic Amines:}

Batches of 6 male rats were sacrificed and weighed brain tissues were homogenized in a Potter-Elvehjem homogenizer with a teflon pestle using cold acidified n-butanol. The biogenic amines were extracted and estimated according to the procedure of Sadavongvivad. ${ }^{4)}$

The recovery experiments were done simultaneously. Recoveries for the different standards were $94 \pm 4 \%$ for dopamine (DA) $85 \pm 6 \%$ for Norepinephrine (NE) and $92 \pm 3 \%$ for 5-Hydroxytryptamine (5-HT). Fluorescence was measured in an Aminco SPF-500 spectrofluorometer. The biogenic amine estimations were made in the whole brains of weaned pups (at day 21 of age) and in the brain regions, viz., cerebral cortex, cerebellum, pons-medulla, corpus striatum and rest of brain at day 90 of postnatal life.

\section{Metal Estimation:}

The distribution of $\mathrm{Cd}, \mathrm{Zn}, \mathrm{Cu}, \mathrm{Fe}$ and $\mathrm{Ca}$ in the brain, liver and kidney were estimated by the wet-ash method, ${ }^{5)}$ using Perkin-Elmer Model 5000 Atomic Absorption Spectrophotometer at days 1, 21 and 90 of postnatal life.

\section{Statistical Analysis:}

The data were analysed by the one way ANOVA across groups, after ascertaining the homogeneity of variance and normality assumptions of the data. If the overall F ratio was found to be significant, post-hoc analyses were provided by computation of the Newman-Keul's Statistic. The significance levels were ascertained at $p<0.05$ and $\mathrm{p}<0.01$. 


\section{Results}

Consummatory Behavior-Dams:

The diet and water consumption in the Cd-exposed pregnant mothers did not differ significantly from the control groups. The water consumption in both the Cdexposed dams - during the gestation period was $32-48 \mathrm{ml} /$ day/rat and did not significantly d:ffer from each other.

\section{Brain Biogenic Amines:}

The effect of the in utero exposure to $\mathrm{Cd}$ on the whole brain levels of NE, DA and 5-HT in 21 day old pups are shown in Table 1. ANOVA indicated main effects of treatment only for the 5-HT levels $\left(\mathrm{F}_{2,15}=5.846, \mathrm{p}<0.05\right)$. Post-hoc analysis revealed a significant increase in the 5-HT levels in both the $\mathrm{Cd}$ exposed groups $(\mathrm{p}<0.05)$. In the 90 days old rats (Table 2$)$ significant increases in the striatal DA $(p<0.01)$ and cortical 5-HT $(p<0.01)$ levels were observed.

Table 1. Brain levels of biogenic amines in 21 day old rats exposed to Cd in utero

\begin{tabular}{lccc}
\hline \multirow{2}{*}{ Group } & \multicolumn{3}{c}{ Brain biogenic amine levels $(\mu \mathrm{g} / \mathrm{g}$ fresh weight $)$ w.b. } \\
\cline { 2 - 4 } & $\mathrm{NE}$ & $\mathrm{DA}$ & $5-\mathrm{HT}$ \\
\hline Control & $0.483 \pm 0.061$ & $0.629 \pm 0.060$ & $0.611 \pm 0.058$ \\
$\mathrm{Cd}_{4.2}$ & $0.492 \pm 0.047$ & $0.557 \pm 0.050$ & $0.751 \pm 0.023^{*}$ \\
$\mathrm{Cd}_{8.4}$ & $0.443 \pm 0.020$ & $0.517 \pm 0.021$ & $0.776 \pm 0.022^{*}$ \\
\hline
\end{tabular}

Values are the mean \pm S.E. of 6 pups (littermate).

$* \mathrm{p}<0.05$ compared to controls.

w.b.: Whole brain.

Table 2. Brain regional levels of biogenic amines in 90 day old rats exposed to Cd in utero

\begin{tabular}{|c|c|c|c|c|c|c|}
\hline \multirow{2}{*}{$\begin{array}{l}\text { Para- } \\
\text { meter }\end{array}$} & \multirow[b]{2}{*}{ Grop } & \multicolumn{5}{|c|}{ Brain regions } \\
\hline & & $\begin{array}{l}\text { Cerebral } \\
\text { cortex }\end{array}$ & $\begin{array}{l}\text { Corpus } \\
\text { striatum }\end{array}$ & Cerebellum & $\begin{array}{l}\text { Pons- } \\
\text { medulla }\end{array}$ & $\begin{array}{l}\text { Rest of } \\
\text { brain }\end{array}$ \\
\hline NE & Control & $0.525 \pm 0.037$ & $0.374 \pm 0.022$ & $0.689 \pm 0.059$ & $0.751 \pm 0.057$ & $0.452 \pm 0.042$ \\
\hline$(\mu \mathrm{g} / \mathrm{g})$ & $\mathrm{Cd}_{8.4}$ & $\begin{array}{l}0.627 \pm 0.045 \\
(119)\end{array}$ & $\begin{array}{l}0.432 \pm 0.033 \\
(115)\end{array}$ & $\begin{array}{c}0.706 \pm 0.069 \\
(102)\end{array}$ & $\begin{array}{l}0.892 \pm 0.073 \\
\quad(118)\end{array}$ & $\begin{array}{c}0.427 \pm 0.023 \\
(94)\end{array}$ \\
\hline DA & Control & $0.789 \pm 0.071$ & $6.148 \pm 0.711$ & $0.252 \pm 0.023$ & $1.780 \pm 0.156$ & $1.924 \pm 0.203$ \\
\hline$(\mu \mathrm{g} / \mathrm{g})$ & $\mathrm{Cd}_{8.4}$ & $\begin{array}{c}0.677 \pm 0.055 \\
(86)\end{array}$ & $\begin{array}{c}10.847 \pm 0.977 * * \\
\text { (176) }\end{array}$ & $\begin{array}{c}0.311 \pm 0.038 \\
(123)\end{array}$ & $\begin{array}{c}1.810 \pm 0.205 \\
(101)\end{array}$ & $\begin{array}{c}1.731 \pm 0.169 \\
(90)\end{array}$ \\
\hline 5-HT & Control & $0.958 \pm 0.104$ & $1.308 \pm 0.163$ & $0.369 \pm 0.051$ & $1.540 \pm 0.131$ & $1.745 \pm 0.138$ \\
\hline$(\mu \mathrm{g} / \mathrm{g})$ & $\mathrm{Cd}_{8.4}$ & $\begin{array}{l}1.404 \pm 0.132 * * \\
(146)\end{array}$ & $\begin{array}{l}1.406 \pm 0.205 \\
(107)\end{array}$ & $\begin{array}{c}0.273 \pm 0.034 \\
(74)\end{array}$ & $\begin{array}{c}1.488 \pm 0.124 \\
(97)\end{array}$ & $\begin{array}{c}1.694 \pm 0.159 \\
(97)\end{array}$ \\
\hline
\end{tabular}

Values are the mean \pm S.E. of 6 rats.

** $\mathrm{p}<0.01$ compared to controls; Values in parentheses indicate the percentage compared to controls. 


\section{Tissue Metal Distribution:}

Table 3 shows the effects of the in utero Cd-exposure on the tissue metal distribution in one day old pups. Statistical analysis showed that a significant increase in Cd level was observed in the liver and kidney $(\mathrm{p}<0.05)$ without any accumulation in the brain. $\mathrm{Zn}$ levels registered a significant increase in the brain $(\mathrm{p}<0.05)$ but a decrease in the liver $(\mathrm{p}<0.05)$. While the $\mathrm{Cu}$ levels were reduced in all the three tissues $(\mathrm{p}<0.05)$, the Fe level was decreased only in kidney $(\mathrm{p}<0.05)$. These changes were observed only in $8.4 \mu \mathrm{g} / \mathrm{ml}$ group.

In the 21 day old pups, the liver $\mathrm{Zn}$ and Fe levels were significantly decreased ( $\mathrm{p}<0.05$ and $\mathrm{p}<0.01$, respectively) in the $8.4 \mu \mathrm{g} / \mathrm{ml} \mathrm{Cd-exposed} \mathrm{group} \mathrm{and} \mathrm{a}$ decrease in the $\mathrm{Cu}$ level $(\mathrm{p}<0.05)$ was observed in the $4.2 \mu \mathrm{g} / \mathrm{ml} \mathrm{Cd}$-exposed group (Table 4).

In the 90 day old rats, no significant alterations in any of the metals were observed except a decrease in the liver $\mathrm{Cu}(\mathrm{p}<0.01)$ in the $8.4 \mu \mathrm{g} / \mathrm{ml} \mathrm{Cd}$-exposed group (Table 5).

Table 3. Tissue metal distribution in 1 day old rats exposed to cadmium in utero

\begin{tabular}{|c|c|c|c|c|c|c|}
\hline \multirow{2}{*}{ Tissue } & \multirow{2}{*}{ Group } & \multicolumn{5}{|c|}{ Metal contents ( $\mu \mathrm{g} / \mathrm{g}$ fresh weight) } \\
\hline & & $\mathrm{Cd}$ & $\mathrm{Zn}$ & $\mathrm{Cu}$ & $\mathrm{Fe}$ & $\mathrm{Ca}$ \\
\hline \multirow[t]{3}{*}{ Brain } & Control & $0.12 \pm 0.05$ & $11.74 \pm 1.09$ & $0.82 \pm 0.09$ & $16.92 \pm 2.48$ & $13.52 \pm 1.15$ \\
\hline & $\mathrm{Cd}_{4.2}$ & $0.14 \pm 0.06$ & $10.63 \pm 0.90$ & $0.90 \pm 0.12$ & $17.21 \pm 1.87$ & $12.48 \pm 1.05$ \\
\hline & $\mathrm{Cd}_{8.4}$ & $0.18 \pm 0.05$ & $15.20 \pm 1.05^{*}$ & $0.60 \pm 0.04 *$ & $15.45 \pm 1.64$ & $13.84 \pm 0.88$ \\
\hline \multirow[t]{3}{*}{ Liver } & Control & $0.22 \pm 0.02$ & $49.32 \pm 3.57$ & $18.39 \pm 0.98$ & $217 \pm 15.11$ & $15.52 \pm 1.22$ \\
\hline & $\mathrm{Cd}_{4.2}$ & $0.25 \pm 0.03$ & $45.27 \pm 4.83$ & $17.33 \pm 1.54$ & $188 \pm 18.78$ & $16.33 \pm 1.18$ \\
\hline & $\mathrm{Cd}_{8.4}$ & $0.33 \pm 0.04 *$ & $37.32 \pm 3.62 *$ & $16.44 \pm 1.13^{*}$ & $168 \pm 19.33$ & $17.65 \pm 2.02$ \\
\hline \multirow[t]{3}{*}{ Kidney } & Control & $0.57 \pm 0.04$ & $15.26 \pm 1.46$ & $1.33 \pm 0.12$ & $23.55 \pm 1.77$ & $22.76 \pm 2.52$ \\
\hline & $\mathrm{Cd}_{4.2}$ & $0.61 \pm 0.05$ & $12.61 \pm 1.12$ & $1.44 \pm 0.24$ & $19.76 \pm 1.94$ & $25.28 \pm 1.98$ \\
\hline & $\mathrm{Cd}_{8.4}$ & $0.72 \pm 0.05^{*}$ & $14.35 \pm 1.43$ & $0.97 \pm 0.13^{*}$ & $17.81 \pm 1.88^{*}$ & $23.66 \pm 2.34$ \\
\hline
\end{tabular}

Values are the mean \pm S.E. of 6 pups (littermate).

$* \mathrm{p}<0.05$; Compared to controls.

Table 4. Tissue metal distribution in 21 day old rats exposed to cadmium in utero

\begin{tabular}{|c|c|c|c|c|c|c|}
\hline \multirow{2}{*}{ Tissue } & \multirow{2}{*}{ Group } & \multicolumn{5}{|c|}{ Metal contents ( $\mu \mathrm{g} / \mathrm{g}$ fresh weight) } \\
\hline & & $\mathrm{Cd}$ & $\mathrm{Zn}$ & $\mathrm{Cu}$ & $\mathrm{Fe}$ & $\mathrm{Ca}$ \\
\hline \multirow[t]{3}{*}{ Brain } & Control & $0.14 \pm 0.06$ & $18.09 \pm 2.12$ & $0.93 \pm 0.20$ & $24.62 \pm 1.81$ & $15.25 \pm 1.22$ \\
\hline & $\mathrm{Cd}_{4.2}$ & $0.16 \pm 0.05$ & $18.18 \pm 1.37$ & $1.02 \pm 0.15$ & $26.74 \pm 2.74$ & $14.34 \pm 1.55$ \\
\hline & $\mathrm{Cd}_{8.4}$ & $0.17 \pm 0.04$ & $20.12 \pm 1.86$ & $1.03 \pm 0.17$ & $25.88 \pm 3.32$ & $16.78 \pm 1.39$ \\
\hline \multirow[t]{3}{*}{ Liver } & Control & $0.30 \pm 0.03$ & $51.27 \pm 4.75$ & $8.32 \pm 0.53$ & $237 \pm 18.01$ & $17.27 \pm 1.43$ \\
\hline & $\mathrm{Cd}_{4.2}$ & $0.42 \pm 0.05$ & $41.37 \pm 3.80$ & $5.97 \pm 0.58^{*}$ & $183 \pm 10.43$ & $18.31 \pm 2.66$ \\
\hline & $\mathrm{Cd}_{8.4}$ & $0.39 \pm 0.04$ & $36.69 \pm 2.54^{*}$ & $6.87 \pm 0.38$ & $165 \pm 11.12 * *$ & $17.88 \pm 2.08$ \\
\hline \multirow[t]{2}{*}{ Kidney } & Control & $0.61 \pm 0.07$ & $21.30 \pm 2.11$ & $10.17 \pm 0.92$ & $27.36 \pm 1.89$ & $27.19 \pm 2.53$ \\
\hline & $\mathrm{Cd}_{4.2}$ & $0.66 \pm 0.08$ & $24.55 \pm 1.97$ & $8.25 \pm 0.55$ & $29.22 \pm 1.99$ & $24.35 \pm 1.66$ \\
\hline
\end{tabular}

Values are the mean \pm S.E. of 6 pups (littermate).

$* \mathrm{p}<0.05$; ** $\mathrm{p}<0.01$; Compared to controls. 
Table 5. Tissue metal distribution in 90 day old rats exposed to cadmium in utero

\begin{tabular}{clccccc}
\multirow{2}{*}{ Tissue } & Group & \multicolumn{5}{c}{ Metal contents $(\mu \mathrm{g} / \mathrm{g}$ fresh weight $)$} \\
\cline { 3 - 7 } & & $\mathrm{Cd}$ & $\mathrm{Zn}$ & $\mathrm{Cu}$ & $\mathrm{Fe}$ & $\mathrm{Ca}$ \\
\hline \multirow{2}{*}{ Brain } & Control & $0.13 \pm 0.04$ & $20.56 \pm 2.59$ & $1.54 \pm 0.23$ & $21.34 \pm 2.71$ & $15.85 \pm 1.64$ \\
& $\mathrm{Cd}_{4.2}$ & $0.14 \pm 0.03$ & $21.43 \pm 1.95$ & $1.23 \pm 0.18$ & $20.66 \pm 2.03$ & $17.21 \pm 1.59$ \\
& $\mathrm{Cd}_{8.4}$ & $0.16 \pm 0.04$ & $19.35 \pm 2.68$ & $1.10 \pm 0.28$ & $18.81 \pm 1.22$ & $16.87 \pm 1.83$ \\
Liver & Control & $0.33 \pm 0.05$ & $38.74 \pm 2.78$ & $8.95 \pm 0.54$ & $237 \pm 18.11$ & $19.80 \pm 1.63$ \\
& $\mathrm{Cd}_{4.2}$ & $0.38 \pm 0.04$ & $32.28 \pm 2.64$ & $6.90 \pm 0.57$ & $243 \pm 25.3$ & $17.86 \pm 1.31$ \\
& $\mathrm{Cd}_{8.4}$ & $0.40 \pm 0.05$ & $36.55 \pm 2.45$ & $5.71 \pm 0.50 * *$ & $213 \pm 18.9$ & $19.67 \pm 1.95$ \\
Kidneyyyyy & $\mathrm{Control}$ & $0.58 \pm 0.14$ & $20.17 \pm 2.33$ & $11.14 \pm 1.09$ & $27.04 \pm 1.63$ & $24.17 \pm 2.50$ \\
& $\mathrm{Cd}_{4.2}$ & $0.69 \pm 0.16$ & $19.22 \pm 1.87$ & $10.06 \pm 2.05$ & $28.67 \pm 1.88$ & $26.88 \pm 3.24$ \\
& $\mathrm{Cd}_{8.4}$ & $0.63 \pm 0.08$ & $19.36 \pm 1.86$ & $12.28 \pm 1.33$ & $25.17 \pm 2.06$ & $28.18 \pm 2.43$ \\
\hline
\end{tabular}

Values are the mean \pm S.E. of 6 rats.

** $\mathrm{p}<0.01$; Compared to control.

\section{DISCUSSION}

The data presented in the present communication show that in utero exposure to a very low level of $\mathrm{Cd}$ produces marked alterations in the brain biogenic amine levels and tissue distribution of $\mathrm{Zn}, \mathrm{Cu}$ and $\mathrm{Fe}$ and some of these changes persist even at the older age after withdrawal of the treatment. These changes were observed despite a low level accumulation of $\mathrm{Cd}$ in the different tissues.

The current findings on the effect of Cd-exposure on the whole brain 5-HT level in one day old pups are in accordance with the earlier report ${ }^{6)}$ where an increase in 5-HT level in different brain regions was observed following $\mathrm{Cd}$ administration through intraventricular cannula in adult rats. A noteworthy feature of the present findings is that the low level in utero Cd-exposure during gestation period caused persistent effects even at 90 days after the withdrawal of exposure, in the form of elevated striatal dopamine and cortical 5-HT. Earlier report ${ }^{7}$ ) indicated an increase in the striatal DA by Cd exposure which returned to normal after withdrawal of treatment but the 5-HT level remained lowered even after withdrawal of treatment. One of the major reasons for the contradictory results may be the fact that in our case the rats were exposed to the metal during the early developmental stage when there is differentiation and rapid cell multiplication.

In spite of the very low dose and short duration of exposure, a low level $\mathrm{Cd}$ transfer in the foetal liver and kidney was observed in the present study. Earlier reports have indicated similar changes at much higher doses. ${ }^{8,9,10)}$ The low accumulation of $\mathrm{Cd}$ in the foetal tissues may be explained by the mode of administration (oral) of this toxicant, in which a very small amount is retained by the dam and by the effective clearance of $\mathrm{Cd}$ from the maternal circulation followed by the incorporation of this metal in the target organs as metallothionein. ${ }^{10}$ )

The decreased $\mathrm{Zn}$ level in the liver in the present experiment is in contrast to the findings of Bunn and Matrone, ${ }^{11)}$ and Schroeder and Nason ${ }^{12)}$ but are in agreement with that of Sowa and Steibert. ${ }^{10)}$ An interesting finding in this study is the 
increase in $\mathrm{Zn}$ level of brain by $\mathrm{Cd}$ exposure. There is a possibility of redistribution of $\mathrm{Zn}$ from foetal liver to other organs following $\mathrm{Cd}$ exposure. ${ }^{13)}$

Some investigators ${ }^{14,15)}$ have reported the decrease of whole body $\mathrm{Cu}$ and $\mathrm{Fe}$ in rat pups following $\mathrm{Cd}$ administration and others ${ }^{10)}$ have reported decrease in $\mathrm{Cu}$ level in foetal liver, kidney, placenta and brain. In the present experiment also, there was a significant decrease in $\mathrm{Cu}$ level in all organs studied and the changes persisted in the liver even after 90 days of withdrawal of exposure, although there was no significant difference in $\mathrm{Cd}$ level compared to the controls at 90 days. These findings indicate that $\mathrm{Cd}$ can cause profound changes in essential metal metabolism even at low level exposure conditions.

\section{ACKNOWLEDGEMENTS}

The skilled technical assistance of Mr. S. G. Husain and Mr. P. K. Awasthi are acknowledged.

\section{REFERENCES}

1) Tischner, K. H. (1980). Cadmium In Experimental and Clinical Neurotoxicology (Edited by Spencer, P. S. and Schaumberg, H. H.), p. 348, Williams and Wilkins, Baltimore.

2) Friberg, L., Piscator, M., Nordberg, G. F. and Kjellstrom, T. (1974). Cadmium in the Environment, CRC Press Inc., Cleveland.

3) Gabbiani, G., Baic, D. and Deziel, C. (1967). Toxicity of cadmium for the central nervous system, Exp. Neurol., 18, 154.

4) Sadavongvivad, C. (1970). Pharmacological significance of biogenic amines in the lungs: 5-Hydroxytryptamine, Br. J. Pharmacol., 38, 353.

5) Berman, E. (1980). Toxic Metals and Their Analysis, Heyden, London.

6) Ribas-Ozonas, B., Ochoa Estomba, M. C. and Santos-Ruiz, A. (1974). Activation of serotonin and 5-hydroxyindoleacetic acid in brain structures after application of cadmium. In Trace Element Metabolism in Animals Vol. 2 (Edited by Hoekstra, W. G., Suttie, J. W., Ganther, H. E. and Mertz, W.), p. 476, University Park Press, Baltimore.

7) Hrdina, P. D., Peters, D. A. V. and Singhal, R. L. (1976). Effects of chronic exposure to cadmium, lead and mercury on brain biogenic amines in the rat, Res. Commun. Chem. Pathol. Pharmacol., 15, 483.

8) Baranski, B., Stetkiewicz, I., Trzcinka-Ochocka, M., Starck, K. and Szymczak, W. (1982). Teratogenicity, foetal toxicity and tissue concentration of cadmium administered to female rats during organogenesis, J. Appl. Toxicol., 2, 255.

9) Steibert, E., Krol, B., Sowa, B., Gralewska, K., Kaninski, M., Kaminska, O. and Kusz, E. (1984). Cadmium induced changes in the histoenzymic activity in liver, kidney, duodenum of pregnant rats, Toxicol. Letters, 20, 127.

10) Sowa, B. and Steibert, E. (1985). Effect of oral cadmium administration on female rats during pregnancy on zinc, copper and iron content in placenta, foetal liver, kidney, intestine and brain, Arch. Toxicol., 56, 256.

11) Bunn, C. R. and Matrone, G. (1966). In vivo interactions of cadmium, copper, zinc and iron in the mouse and rat, J. Nutr., 90, 395.

12) Schroeder, H. A. and Nason, A. P. (1974). Interactions of trace metals in rat tissues, cadmium and nickel with zinc, chromium, copper and manganese, J. Nutr., 104, 167. 
13) Waalkes, M. P., Thomas, J. A. and Bell, J. U. (1982). Induction of hepatic metallothionein in the rabbit fetus following maternal cadmium exposure, Toxicol. Appl. Pharmacol., 62, 211.

14) Pond, W. G. and Walker, E. F. (1975). Effect of dietary Ca and Cd level of pregnant rats on reproduction and on dam and progeny tissue mineral concentration, Proc. Soc. Exp. Biol. Med., 148, 665.

15) Petering, H. G. (1978). Some observations on the interactions of zinc, copper and iron metabolism in lead and cadmium toxicity. Environ. Health Perspect., 25, 141. 